\title{
Distribution and timing of Holocene and late Pleistocene glacier fluctuations in western Mongolia
}

\author{
Frank LEHMKUHL, ${ }^{1}$ Michael KLINGE, ${ }^{2}$ Henrik ROTHER, ${ }^{3}$ Daniela HÜLLE ${ }^{4}$ \\ ${ }^{1}$ Department of Geography, RWTH Aachen University, Aachen, Germany \\ ${ }^{2}$ Department of Geography, Göttingen University, Göttingen, Germany \\ ${ }^{3}$ Institute of Geography and Geology, University of Greifswald, Greifswald, Germany \\ ${ }^{4}$ Institute of Geography, University of Cologne, Cologne, Germany \\ Correspondence: Frank Lehmkuhl< frank.lehmkuhl@geo.rwth-aachen.de>
}

\begin{abstract}
Despite being a key location for paleoglaciological research in north-central Asia, with the largest number of modern and Pleistocene glaciers, and in the transition zone between the humid Russian Altai and dry Gobi Altai, little is known about the precise extent and timing of Holocene and late Pleistocene glaciations in western Mongolia. Here we present detailed information on the distribution of modern and late Holocene glaciers, and new results addressing the geomorphological differentiation and numerical dating (by optically stimulated luminescence, OSL) of Pleistocene glacial sequences in these areas. For the Mongolian Altai, geochronological results suggest large ice advances correlative to marine isotope stages (MIS) 4 and 2. This is in contrast to results from the Khangai mountains, central Mongolia, showing that significant ice advances additionally occurred during MIS3. During the Pleistocene, glacial equilibrium-line altitudes (ELAs) were $\sim 500$ to $>1000 \mathrm{~m}$ lower in the more humid portion of the Russian and western Mongolian Altai, compared to $300-600 \mathrm{~m}$ in the drier ranges of the eastern Mongolian Altai. Pleistocene ELAs in the Khangai mountains were depressed by 700-1000 m, suggesting more humid conditions at times of major glaciation than in the eastern Mongolian Altai. This paleo-ELA pattern reveals that the precipitation gradient from the drier to the more humid regions was more pronounced during glacial times than at present.
\end{abstract}

KEYWORDS: glacial geomorphology, glacier fluctuations, glacier mapping, mountain glaciers, paleoclimate

\section{INTRODUCTION}

This paper aims to summarize the extent and timing of Holocene and Pleistocene glaciations in western Mongolia based on selected region in the Altai and western Khangai mountains (Figs 1-6; see Fig. 1a for locations). Few comprehensive studies considering Quaternary glaciation of the entire Altai region are available (e.g. Lehmkuhl and others, 2011; Blomdin and others, 2014).

The Altai mountains span four different countries (Russia, Mongolia, China, Kazakhstan), with major mountain ranges represented by the Russian Altai in the north and west, the Mongolian Altai in the east and the Chinese Altai in the south. Towards the southeast the Mongolian Altai extend into the Gobi Altai. East of the Mongolian Altai, the socalled 'Valley of Great Lakes' separates the Altai from the Khangai mountains in central Mongolia, which trend $600 \mathrm{~km}$ from northwest to southeast (Fig. 1a).

The modern climatic conditions are of continental type showing large temperature variations with mean winter temperatures below $-20^{\circ} \mathrm{C}$ and mean summer temperatures of $\sim 20^{\circ} \mathrm{C}$. The highest amount of annual precipitation occurs in the western Altai (above $1000 \mathrm{~mm}$ ), in regions climatically influenced by the westerlies. The eastern part of the Altai is situated in a rain shadow and experiences more arid conditions (200-400 mm). In the basins of the Valley of Great Lakes the annual precipitation decreases to $<50 \mathrm{~mm}$. Further east, in the Khangai, the annual precipitation rises again, reaching $>400 \mathrm{~mm}$. There is a pronounced seasonal precipitation distribution, with $70-80 \%$ of annual precipitation falling during the summer months.
The topography a nd climatic conditions of the Altai mountains are major factors determining the characteristics and dynamics of late Quaternary glaciations in this region. In the western and southern Altai the alpine relief features steep V-shaped valleys, while intramontane basins divide the eastern Mongolian Altai into several large mountain massifs, of which the higher parts have been intensively shaped by glacial erosion. The summits, which lie above an old planation surface, reach $>4000$ ma.s.l.

In western literature, only a few results have been published detailing historic and Holocene glacier variations in Mongolia (e.g. Klinge, 2001; Lehmkuhl, 2012; Kamp and others, 2013). Under modern conditions glaciation in Mongolia is restricted to mountains above $\sim 3400$ ma.s.l. At present, numerous plateau glaciers, cirque glaciers and a few valley glaciers are found across the Mongolian Altai, while only a single small ice field survives in the Khangai at Otgontenger (3964 m a.s.l.; Fig. 1b). In addition, Osipov and others (2013) show a single small glacier $\left(0.12 \mathrm{~km}^{2}\right)$ on the Mongolian side of Munku Sardyk (Sayan range, north of Khövgöl lake). Krumwiede and others (2014) note that estimates of the glacierized area of Mongolia range from 300 to $659 \mathrm{~km}^{2}$. According to Klinge (2001), the modern glaciation across Mongolia covers an area of $\sim 850 \mathrm{~km}^{2}$. Version 3.2 of the Randolph Glacier Inventory (Pfeffer and others, 2014) calculated $627 \mathrm{~km}^{2}$. Currently, equilibriumline altitudes (ELAs) increase from 3200 ma.s.l. in the western part of the Mongolian Altai (Tavan Bogd) to $3800 \mathrm{~m}$ a.s.I. in the southeastern Mongolian Altai and at Otgontenger in central Mongolia. 
Based on fieldwork and aerial photos the extent of the Little Ice Age (LIA) glaciation was mapped for three regions in western Mongolia. (1) For the Turgen-Kharkhiraa massif (northern Mongolian Altai; Fig. 1a, No. 4) Lehmkuhl (1998, 2012) calculated ELA values for 99 glaciers and their LIA ice extent using the toe-to-summit altitude method (TSAM; cf. Benn and Lehmkuhl, 2000). Modern ELAs calculated by the TSAM show consistent values as estimated from firn lines on modern glaciers surveyed through aerial reconnaissance and field observations. The ELA depression ( $\triangle E L A)$ for the LIA was calculated at $\sim 80 \mathrm{~m}$ with respect to the present, with an associated reduction of the glaciated area from $157.6 \mathrm{~km}^{2}$ (LIA) to $69.7 \mathrm{~km}^{2}$ (in 1991) (Lehmkuhl, 2012). (2) For the Tsambagarav massif (central Mongolian Altai; Fig. 1a, No. 5) the $\Delta$ ELA for the LIA was calculated at only $\sim 30 \mathrm{~m}$, while the total glaciated area decreased from $110.3 \mathrm{~km}^{2}$ (LIA) to $80.7 \mathrm{~km}^{2}$ (1991; Klinge, 2001). (3) The $\Delta$ ELA for the LIA at the Munkh Khairkhan (southern Mongolian Altai; Fig. 1a, No. 6) was estimated at $\sim 50 \mathrm{~m}$ (Klinge, 2001).

During the Pleistocene, numerous large valley and cirque glaciers existed in eastern and central Mongolia. The ice masses formed extensive systems of interconnected valley glaciers, constituting separate glaciation centers within the Mongolian Altai and Khangai (Lehmkuhl and others, 2011; Rother and others, 2014). The maximum extent of the Pleistocene glaciations has been determined from the distribution of glacial landforms such as large hummocky moraines which are easily visible on aerial photographs and satellite images (Klinge, 2001; Blomdin and others, 2014).

The spatial distribution and sedimentary composition of moraine landforms in Mongolia vary based on relief, geology and the tectonic situation. Using geomorphological criteria, the Quaternary moraines can usually be differentiated into three main moraine systems (Lehmkuhl and others, 2011) comprising (1) Holocene and, in particular, LIA moraines, characterized by a fresh morainic topography without any sediment and soil cover; (2) the larger $M_{1}$ moraines further down-valley, which can be further differentiated into three sub-stages $\left(M_{1 a}, 1 b, 1 c\right)$, of which the oldest $\left(M_{1 c}\right)$ shows extensive periglacial modifications and weathered carbonate crusts; and (3) relics of the eroded $\mathrm{M}_{2}$ moraine, which represents the oldest phase of glaciation and is connected to relics of a high-lying terrace $\left(T_{2}\right)$ and associated with dispersed erratic boulders and glacial trimlines. The $M_{1}$ moraines are usually connected to the main terrace $\left(T_{1}\right)$ and/or alluvial fan system $\left(A_{1}\right)$ (Grunert and others, 2000). These features typically show an aeolian cover and kastanozem soil with a carbonate-enriched layer that is correlated to the last glacial cycle. The $M_{2}$ sequence is tentatively correlated to the penultimate glaciation, while the relative down-valley positions of these features indicate an ice extent slightly larger than during the last glaciation (Lehmkuhl and others, 2004, 2011).

Based on the altitudinal position of terminal moraines associated with the local Last Glacial Maximum (LLGM; $M_{1}$, maximum extent of glaciers during the last glacial cycle) we calculate that LLGM paleo-snowlines (ELAs) were at $\sim 3000 \mathrm{~m}$ a.s.l. in the western and central Mongolian Altai, increasing to $3100 \mathrm{~m}$ a.s.I. in the southern Mongolian Altai, while data from the Khangai suggest LLGM paleo-ELAs at 3000 ma.s.l. in the west and $\sim 2800$ ma.s.l. in the east (Klinge, 2001; Lehmkuhl and others, 2011).

First absolute chronologies for major late Pleistocene ice advances in Mongolia have been obtained by Klinge (2001),
Gillespie and others (2008), Lehmkuhl and others (2011) and Rother and others (2014). However, considering the vast size of the region there is still a lack of numerical age control for most moraines in these areas, severely limiting the development of a comprehensive glacial model for Mongolia.

\section{LUMINESCENCE DATING METHODS}

Eighteen samples from the three regions (O1-4, Z1-2, K1-3) (Table 1 ) were examined by optically stimulated luminescence (OSL) dating to gain information about the timing of critical late Quaternary geomorphological and sedimentological processes. Usually quartz is used in luminescence dating studies on Holocene deposits, but, as reported by Hülle and others (2010) and Lehmkuhl and others (2007, 2012), quartz samples from southern and central Mongolia exhibit feldspar contaminations compromising the usability of the luminescence signal. This problem was also observed for the samples in this study, so the quartz fraction was discarded and the feldspar fraction was used for dating. The sample preparation and the applied quality criteria are described in detail by Hülle and others (2010) and Lehmkuhl and others (2012). For the dating procedure, small aliquots with a grain layer of $1 \mathrm{~mm}$ diameter of the $100-200 \mu \mathrm{m}$ grain size were used; only the three samples from profiles $\mathrm{K} 1$ and $\mathrm{K} 2$ are polymineralic fine-grain samples, due to their fine-grained matrix. All measurements were carried out on automated Risø TL/OSL readers (TL-DA20), equipped with ${ }^{90} \mathrm{Sr} /{ }^{90} \mathrm{Y} \beta$-sources for irradiation and EMI 9235 photomultiplier tubes for luminescence detection (Bøtter-Jensen and others, 2003). Infrared (IR) LEDs were used for stimulation; the detection wavelength was 380$440 \mathrm{~nm}$, isolated by an interference filter D410, LOT Oriel. For 14 samples, the usual single-aliquot regenerative-dose (SAR) protocol was used and for 10 of them the equivalent dose was calculated with the central age model of Galbraith and others (1999). Exceptions are made for four samples from profiles $\mathrm{O} 2$ and $\mathrm{O} 3$, which are calculated with the finite mixture model of Galbraith and Green (1990), due to a high data scatter. Note that the ages are not corrected for fading and thus have to be regarded as minimum ages. Fading measurements from comparable samples from this region show that a systematic age underestimation of $\sim 20 \%$ has to be taken into account. This is not applicable for the remaining four 'old' ages from profiles Z2 and K1, which were measured with the post-IR-IR protocol using elevated stimulation temperatures to derive a dating result that is much less affected by fading than the conventional IR stimulated luminescence (IRSL) signal measured at $50^{\circ} \mathrm{C}$. For this, the protocol suggested by Thiel and others (2011) was selected, using a stimulation temperature of $290^{\circ} \mathrm{C}$ after preheating at $320^{\circ} \mathrm{C}$ and an IR bleach at $50^{\circ} \mathrm{C}$.

Dose rates are based on laboratory high-resolution $\gamma$-spectrometry results using $800 \mathrm{~g}$ of bulk material. The dose rate was calculated taking variations in the water content into account. An internal potassium content of $12.5 \pm 0.5 \%$ (Huntley and Baril, 1997) and an $\alpha$-efficiency factor of $0.07 \pm 0.02$ were assumed. The contribution of cosmic rays to the dose rate was calculated following Prescott and Hutton (1995). All dose rate results are given in Table 1.

Due to transport processes which may not be sufficient to bleach the sample completely, the dating of moraine sequences has proved to be problematic, as discussed in greater detail by Fuchs and Owen (2008). To obtain robust 
Table 1. Luminescence dating results. For each sample the depth, the radionuclide contents determined by $\gamma$-spectrometry, the water content and the resulting dose rate are presented as well as the equivalent doses (determined with the central age model; only the samples O2-1, O2-2, O3-1 and O3-4 were calculated with the finite mixture model), the number of measured aliquots $(n)$, the relative standard deviation of these aliquots and the resulting age estimates. Note that the ages are not corrected for signal loss due to fading and thus have to be interpreted as minimum ages. Exceptions are the ages written in italics (Z2-1, Z2-2, K1-1 and K1-2) which were determined with the post$I R-I R_{290^{\circ} \mathrm{C}}$ protocol for which fading is relevant only to a minor degree. The $U$, Th and $\mathrm{K}$ were not measured for O1-4 and assumed from the adjacent sample O1-3

\begin{tabular}{|c|c|c|c|c|c|c|c|c|c|c|c|}
\hline \multirow[t]{2}{*}{ Section } & Location & Depth & $U$ & Th & K & Dose rate & $\begin{array}{l}\text { Water } \\
\text { content }\end{array}$ & Equivalent dose & $n$ & rsd & Age \\
\hline & ma.s.l. & $\mathrm{cm}$ & ppm & ppm & $\%$ & $\mathrm{~Gy} \mathrm{ka}^{-1}$ & $\%$ & Gy & & $\%$ & ka \\
\hline O1-1 & $47.6361^{\circ} \mathrm{N}$ & 11 & $1.9 \pm 0.1$ & $8.1 \pm 0.4$ & $2.5 \pm 0.1$ & $4.1 \pm 0.1$ & 2 & $11.1 \pm 0.8$ & 8 & 11 & $2.8 \pm 0.3$ \\
\hline O1-2 & $97.13249^{\circ} \mathrm{E}$ & 40 & $2.3 \pm 0.1$ & $10.0 \pm 0.5$ & $2.4 \pm 0.1$ & $4.2 \pm 0.2$ & 2 & $14.5 \pm 1.0$ & 15 & 12 & $3.5 \pm 0.3$ \\
\hline O1-3 & (1976 m a.s.l.) & 120 & $2.2 \pm 0.1$ & $9.5 \pm 0.5$ & $2.5 \pm 0.1$ & $4.2 \pm 0.2$ & 4 & $37.8 \pm 2.41$ & 37 & 44 & $9.1 \pm 0.8$ \\
\hline O1-4 & & 155 & & & & & 5 & $110.8 \pm 14.8$ & 24 & 38 & $26.9 \pm 3.8$ \\
\hline O2-1 & $47.64287^{\circ} \mathrm{N}$ & 48 & $2.5 \pm 0.1$ & $9.1 \pm 0.5$ & $2.3 \pm 0.1$ & $4.1 \pm 0.2$ & 5 & $56.0 \pm 4.3$ & 42 & 51 & $13.5 \pm 1.4$ \\
\hline $\mathrm{O} 2-2$ & $\begin{array}{c}97.14026^{\circ} \mathrm{E} \\
(1984 \mathrm{~m} \text { a.s.l. })\end{array}$ & 92 & $2.4 \pm 0.1$ & $8.3 \pm 0.4$ & $2.3 \pm 0.1$ & $4.0 \pm 0.2$ & 5 & $324.4 \pm 19.0$ & 30 & 29 & $81.8 \pm 7.4$ \\
\hline O3-1 & $47.68959^{\circ} \mathrm{N}$ & 35 & $2.1 \pm 0.1$ & $10.5 \pm 0.5$ & $1.8 \pm 0.1$ & $3.2 \pm 0.2$ & 6 & $82.2 \pm 4.9$ & 24 & 38 & $25.1 \pm 2.4$ \\
\hline O3-2 & $\begin{array}{l}97.25225^{\circ} \mathrm{E} \\
(2090 \text { m a.s.l. })\end{array}$ & 50 & $2.2 \pm 0.1$ & $12.5 \pm 0.6$ & $2.7 \pm 0.1$ & $4.5 \pm 0.3$ & 1 & $122.2 \pm 7.2$ & 40 & 26 & $27.1 \pm 2.5$ \\
\hline O4-2 & $\begin{array}{c}47.68843^{\circ} \mathrm{N} \\
97.27974^{\circ} \mathrm{E} \\
(2130 \mathrm{~m} \text { a.s.l. })\end{array}$ & 35 & $2.0 \pm 0.1$ & $10.2 \pm 0.5$ & $2.5 \pm 0.1$ & $4.4 \pm 0.1$ & 3 & $48.8 \pm 10.5$ & & & $11.6 \pm 2.4$ \\
\hline $\mathrm{Z} 1-1$ & $48.5028^{\circ} \mathrm{N}$ & $42-48$ & $1.5 \pm 0.1$ & $5.7 \pm 0.4$ & $1.8 \pm 0.1$ & $3.3 \pm 0.2$ & 1 & $43.1 \pm 2.3$ & 24 & 8 & $13.2 \pm 1.2$ \\
\hline $\mathrm{Z} 1-2$ & $\begin{array}{c}88.9878^{\circ} \mathrm{E} \\
(2324 \mathrm{~m} \text { a.s.l. })\end{array}$ & $80-86$ & $1.7 \pm 0.1$ & $7.0 \pm 0.4$ & $1.8 \pm 0.1$ & $3.4 \pm 0.2$ & 3 & $48.5 \pm 3.4$ & 24 & 24 & $14.2 \pm 1.4$ \\
\hline $\mathrm{Z} 2-1$ & $48.5327^{\circ} \mathrm{N}$ & $375-381$ & $3.4 \pm 0.2$ & $7.9 \pm 0.5$ & $1.9 \pm 0.1$ & $3.7 \pm 0.4$ & 15 & $266.6 \pm 18.1$ & 11 & 15 & $71.2 \pm 4.8$ \\
\hline $\mathrm{Z} 2-2$ & $\begin{array}{c}89.0181^{\circ} \mathrm{E} \\
(2382 \mathrm{~m} \text { a.s.l.) }\end{array}$ & $405-411$ & $2.1 \pm 0.1$ & $7.9 \pm 0.5$ & $1.9 \pm 0.1$ & $3.8 \pm 0.3$ & 4 & $366.2 \pm 113$ & 7 & 10 & $97.6 \pm 30.1$ \\
\hline $\mathrm{Z} 3-1$ & $48.5396^{\circ} \mathrm{N}$ & $52-58$ & $2.0 \pm 0.1$ & $8.8 \pm 0.5$ & $1.9 \pm 0.1$ & $2.9 \pm 0.3$ & 43 & $17.1 \pm 1.0$ & 20 & 10 & $5.8 \pm 0.6$ \\
\hline $\mathrm{Z} 3-2$ & $\begin{array}{c}89.0307^{\circ} \mathrm{E} \\
(2455 \mathrm{~m} \text { a.s.l. })\end{array}$ & $70-76$ & $3.0 \pm 0.2$ & $11.4 \pm 0.7$ & $2.3 \pm 0.1$ & $4.1 \pm 0.4$ & 21 & $42.0 \pm 2.3$ & 24 & 12 & $10.4 \pm 0.6$ \\
\hline $\mathrm{K} 1-1(\mathrm{fg})$ & $48.6072^{\circ} \mathrm{N}$ & $30-36$ & $2.5 \pm 0.1$ & $9.5 \pm 0.6$ & $1.9 \pm 0.1$ & $4.0 \pm 0.6$ & 12 & $231.8 \pm 12.8$ & 20 & 2 & $57.8 \pm 9.1$ \\
\hline $\mathrm{K} 1-2$ (fg) & $\begin{array}{c}88.7619^{\circ} \mathrm{E} \\
(2052 \mathrm{~m} \text { a.s.l. })\end{array}$ & $43-49$ & $2.7 \pm 0.1$ & $9.6 \pm 0.5$ & $1.9 \pm 0.1$ & $4.3 \pm 0.5$ & 9 & $370.4 \pm 18.9$ & 24 & 6 & $85.6 \pm 10.4$ \\
\hline K2-1(fg) & $\begin{array}{c}48.5981^{\circ} \mathrm{N} \\
88.4258^{\circ} \mathrm{E} \\
(2091 \mathrm{~m} \text { a.s.l. })\end{array}$ & $112-118$ & $2.4 \pm 0.1$ & $9.9 \pm 0.6$ & $2.0 \pm 0.1$ & $4.3 \pm 0.5$ & 6 & $58.8 \pm 3.0$ & 24 & 3 & $13.6 \pm 1.6$ \\
\hline
\end{tabular}

minimum age estimates for the past glaciations, overlying aeolian or glaciofluvial deposits of the different morphologic sequences were sampled. In addition, four samples were taken from fluvial sand underneath till (sections O2 and Z2) and two from lacustrine deposits (K1) above moraines.

\section{RESULTS}

As described above, several Holocene and Pleistocene stages of glaciation can be differentiated based on geomorphological criteria. The largest and best-preserved moraines are associated with ice advances during the last glacial cycle $\left(M_{1}\right)$. These moraine sequences are characterized by a fresh glacial relief featuring moraine ridges and dead-ice depressions, while their hummocky surfaces are littered with numerous big boulders. Stacked lateral moraines and glacial trimlines are often found in the lower valley portions. The main glaciofluvial terrace $T_{1}$, which is commonly covered by a layer of aeolian sediment, can be traced to this moraine and was formed by meltwater deposition during the $M_{1}$-advance phase. In the field this moraine system can be further divided into two sub-stages $\left(M_{1 b}, M_{1 c}\right)$. Further up-valley, the $M_{1 b / c}$ moraines are often followed by a third and much smaller moraine system $\left(M_{1 a}\right)$, representing terminal moraines that formed during a short period of stagnation at the beginning of deglaciation during the last termination.

Although there is a difference in the total glaciated areas during the three $M_{1}$ stages, no significant difference in the elevation and distance of the associated terminal moraines exists. This prohibits a separate ELA calculation for every $M_{1}$ stage and the $\triangle E L A$ is delineated for the LGM as one.

\subsection{Otgontenger (western Khangai)}

Mapping and fieldwork concentrated on Bogdin gol valley, west of Otgontenger peak $\left(47^{\circ} 37^{\prime} \mathrm{N}, 97^{\circ} 31^{\prime} \mathrm{E}\right.$; Figs $1 \mathrm{~b}$ and 2 ). Site and sample locations for luminescence and cosmogenic radionuclide (CRN) surface exposure dating are shown in Figure 2. According to CRN dating efforts of Rother and others (2014), a total of 21 samples were collected from five moraines ranging in altitude from 2100 to $2500 \mathrm{~m}$ a.s.l. Most samples were obtained from glacial boulders, but in one case an ice-overridden smooth bedrock surface was also sampled. Site context and analytical procedures for $\mathrm{CRN}$ dating are described in detail in Rother and others (2014). Table S1 (see Supplementary material (http://igsoc.org/hyperlink/71a030_supp.pdf)) shows the CRN results from the Otgontenger sequence using the updated ${ }^{10}$ Be reference production rate of Heyman (2014). This revised production rate is based on a recent compilation 


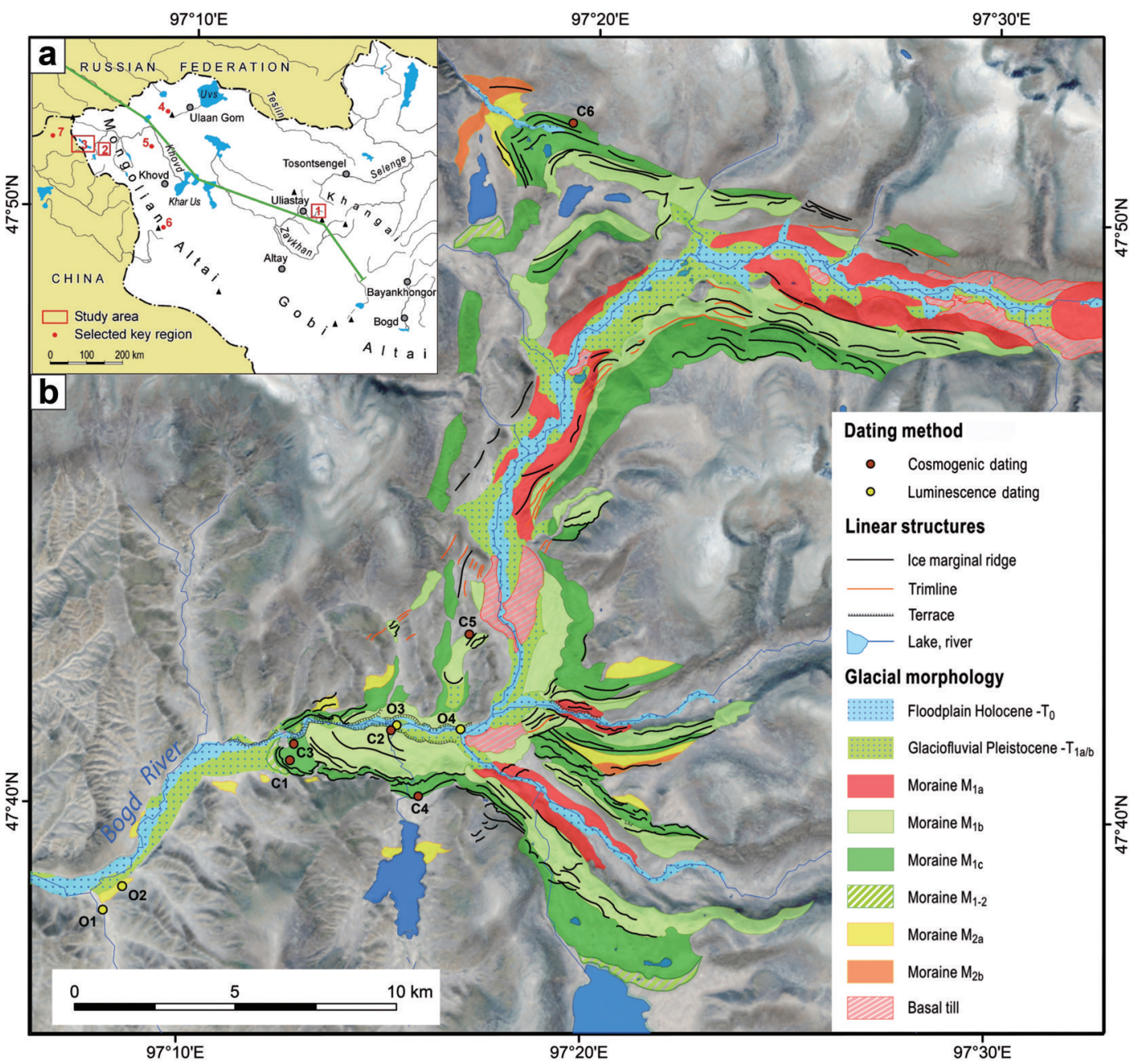

Fig. 1. (a) Study areas and cross section (green line). $1=$ Otgontenger, $2=$ Tsengel, $3=$ Khurgannuur, $4=$ Turgen-Kharkhiraa, $5=$ Tsambagarav, 6 = Munkh Khairkhan, 7 = Kanas Valley (Chinese Altai). (b) Geomorphic map of late Quaternary glaciation and selected sampling sites near Otgontenger, Khangai. Background image: STRM DTM and Landsat 8 image from 22 September 2014.

and recalculation of the global calibration datasets, yielding a significantly lower ${ }^{10} \mathrm{Be}$ production rate than the previous ${ }^{10} \mathrm{Be}$ reference production rate of Balco and others (2008). As a consequence, moraine exposure ages from Otgontenger (Rother and others, 2014) increase by 9\% or between 1.3 and $5.4 \mathrm{ka}$ across the period of interest (Table S1 (http://igsoc.org/hyperlink/71a030_supp.pdf)).
CRN dating shows that moraines associated with the maximum LLGM ice advance at Otgontenger yield mean ages of $\sim 40 \mathrm{ka}$ (C3), thus falling into marine isotope stage (MIS) 3. Similarly, a high-lying lateral moraine at a transfluence pass in the northwest of the Otgontenger area (C6) also gives a late MIS3 mean site age of $41.1 \pm 5.8 \mathrm{ka}$. Interestingly, an ice extent very similar to the local MIS3
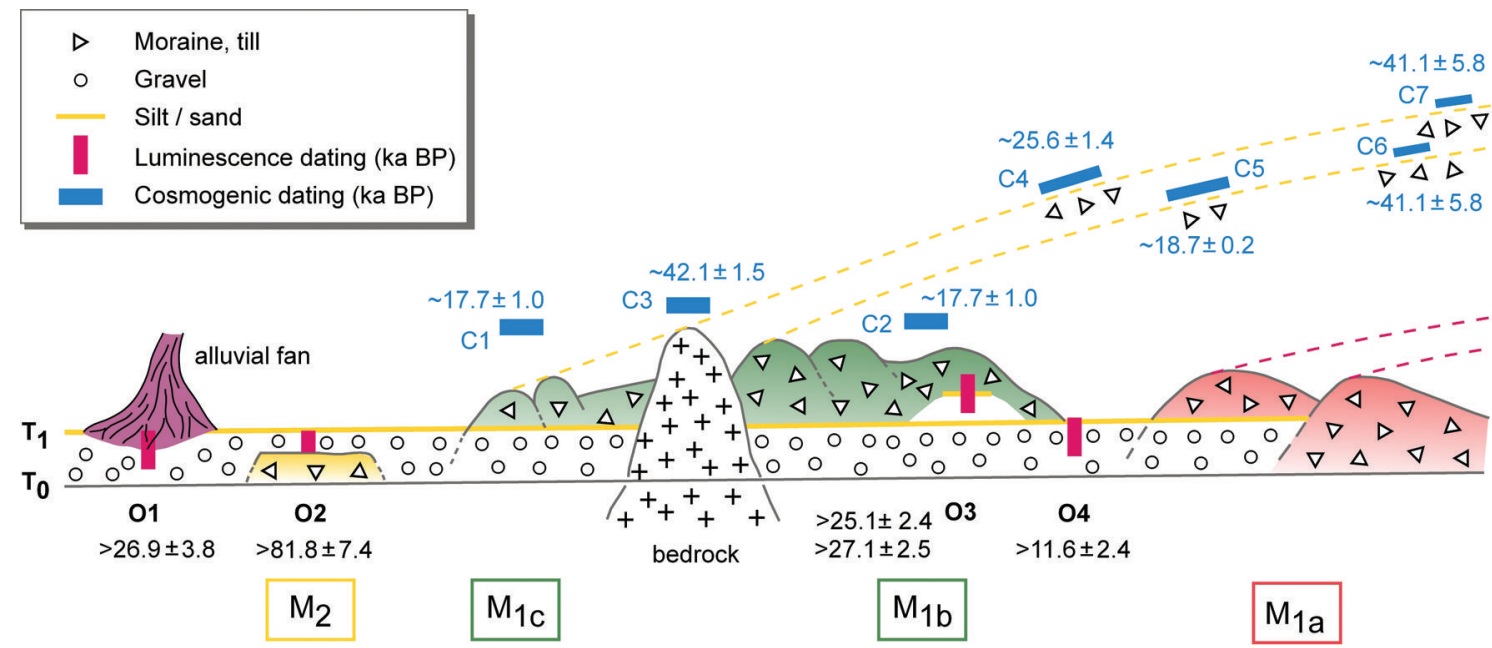

Fig. 2. Schematic cross sections showing the connection between ice-marginal moraines, terraces and aeolian cover beds at Otgontenger. 
limits (=LLGM) was also reached during MIS2, as indicated by a high lateral moraine near Saran nuur lake (C4), which returned a mean site age of $25.6 \pm 1.4 \mathrm{ka}$. Following recession from these limits, a large terminal moraine $(\mathrm{C} 1$, $\mathrm{C} 2)$, comprising multiple moraine ridges and extended hummocky terrain, formed on the valley floor below the C4 lateral moraine. New and detailed geomorphological mapping of this moraine complex and its associated outwash terraces allows the differentiation of two moraine sub-stages which we designate as $M_{1 b 1}$ and $M_{1 b 2}$ (Figs $1 b$ and 2). CRN dating of this moraine (six boulders) returns overlapping site ages of $16.65 \pm 1.2 \mathrm{ka}$ for $\mathrm{C} 1$ and $18.37 \pm 1.4 \mathrm{ka}$ for $\mathrm{C} 2$, yielding a cumulative mean moraine age of $17.7 \pm 1.0 \mathrm{ka}$ (C1 and C2). Close to the C2 site, glaciofluvial sands, exposed stratigraphically below the moraine, yielded consistent OSL dates of $>25.1 \pm 2.4$ and $>27.1 \pm 2.1 \mathrm{ka}(\mathrm{O} 3)$, suggesting deposition slightly before the last major ice advance. Therefore both data sources, CRN and OSL, place this ice advance into MIS2 between $>27.1$ and $17.7 \mathrm{ka}$. Taken together, these results provide evidence suggesting the correlation of the $M_{1 c}$ moraines to ice advances during MIS3 and the $M_{1 b}$ moraines are part of the MIS2 sequence. Three small $M_{1}$ terminal moraines were identified upstream of the main valley of Arschaani gol, which are connected to a system of $T_{1 a}$ terraces. Sand and silt on the $T_{1 a}$ terrace $(O 4)$ in front of this $M_{1 \text { a }}$ moraine complex supplied a Late-glacial OSL age of $>11.6 \pm 2.4 \mathrm{ka}$, which should be considered a minimum age for the $M_{1}$ advance.

Further glacial sediments, probably associated with an earlier ice advance and the oldest moraine $\left(M_{2}\right)$ in the valley, are located $\sim 5 \mathrm{~km}$ downstream of the LLGM moraine (O2, Fig. 2). These deposits are covered by $>1 \mathrm{~m}$ of aeolian sand and silt, yielding OSL ages ranging from $>81.8 \pm 7.4 \mathrm{ka}$ at the base to $>13.5 \pm 1.4 \mathrm{ka}$ in the upper part. These ages are consistent with our interpretation that the $M_{2}$ moraine formed during the penultimate glacial cycle.

At Otgontenger, ELAs during the LGM were depressed to $\sim 3000 \mathrm{~m}$ a.s.l. The modern ELA of $3800 \mathrm{ma}$ a.s.l. was estimated from the small ice cap on Otgontenger and suggests a $\triangle E L A$ of $800-1000 \mathrm{~m}$ for the Khangai.

\subsection{Tsengel Khairkhan}

The Tsengel Khairkhan is an isolated mountain massif in the central Mongolian Altai $\left(48^{\circ} 32^{\prime} \mathrm{N}, 89^{\circ} 01^{\prime} \mathrm{E}\right.$; Figs $1 \mathrm{a}$ and 2). Our fieldwork targeted a large terminal moraine complex located on the southern slopes of this mountain system (Figs 3 and 4).

Significant morainic landforms and glacial deposits are preserved in the lower portion of the trunk valley and in the mountain foreland. These moraines show a fresh relief with a hummocky surface and many small dead-ice depressions. The moraine front is steep and $>10 \mathrm{~m}$ high. Here too these accumulations can be divided into the three $M_{1}$ moraine systems, but at the base they are additionally framed by a shallow $M_{1-2}$ moraine, which can be traced to relics of the highest glaciofluvial terrace preserved in the area. The main LLGM moraine consists of two distinct $M_{1 c}$ moraine ridges, which are connected to lateral moraines found along the valley flanks. The $M_{1 b}$ terminal moraine is framed by the $M_{1 c}$ terminal moraine. This large $M_{1 b c}$ moraine complex encloses a small terminal moraine of the youngest $M_{1 \text { a }}$ stage with section Z3 situated in a dead-ice depression of the $M_{1 b c}$ moraine. An OSL sample from aeolian sandy silt recovered from the base of the depression gave an age of
$>10.4 \pm 0.6 \mathrm{ka}$, probably indicating aeolian deposition during the Late-glacial warming phase and providing a minimum age of the $M_{1 b c}$ moraines. Older remnants of deeply eroded $M_{2}$ moraines extend $>3 \mathrm{~km}$ downstream from the $M_{1}$ moraines, traceable by trimlines and erratic boulders along the slopes until two terminal moraines $\left(M_{2 a}, M_{2 b}\right)$. Behind the $M_{2 b}$ terminal moraine, $>1 \mathrm{~m}$ of aeolian sand is accumulated (Z3). Dating samples recovered from this deposit at 40 and $70 \mathrm{~cm}$ depth returned OSL ages of $13.2 \pm 1.1 \mathrm{ka}$ and $14.2 \pm 1.4 \mathrm{ka}$, suggesting an onset of dust trapping by developing vegetation during the Late-glacial phase. Approximately $100 \mathrm{~m}$ outward from the western margins of the $M_{1}$ terminal moraines, two $M_{2}$ lateral moraine ridges are located. Between the moraines a river channel cuts $>10 \mathrm{~m}$ into the $M_{2}$ moraine (Z2). Two samples were taken for OSL (post-IR) dating, providing ages of $>97.6 \pm 30.1 \mathrm{ka}$ from a layer of interbedded fluvial sand/silt $3.4 \mathrm{~m}$ below the surface, and an age of $>71.2 \pm 4.8 \mathrm{ka}$ from the till below that layer, indicating that the $M_{2}$ moraines date to the penultimate glaciation, although residual signals due to incomplete bleaching in these depositional environments need to be considered.

The modern ELA in this area is at $\sim 3420$ ma.s.l., while the reconstructed ELA during the LLGM was 3120 ma.s.I., resulting in a $\triangle E L A$ of $300 \mathrm{~m}$.

\subsection{Khurgan nuur}

The Khurgan and Khoton nuur are glacial lakes located in the western Mongolian Altai $\left(48^{\circ} 40^{\prime} \mathrm{N}, 88^{\circ} 48^{\prime} \mathrm{E}\right.$; Fig. 1a, No. 3) formed in a glacial trough associated with a very large Pleistocene valley glacier extending from the Tavan Bogd (the highest peak of Mongolia; 4374 ma.s.I.) in a southeasterly direction. In the downstream portion of the trough, voluminous morainic sediments filled up an intramontane tectonic basin from which the Khovd river cuts a steep and narrow gorge across the outer mountain range (Fig. 5). Figure 6 shows an overview of the geomorphological setting and the locations of the examined sediment sections in this study area.

Within the hummocky terrain of the very extensive icemarginal zone, several systems of terminal moraines can be identified. An important feature is the incorporation of large amounts of glaciolacustrine clay and silt into the moraine, evidencing that a large proglacial lake filled the glacial trough before and during the late Pleistocene ice advances and associated retreat stages. During glacial advances these sediments were pushed together, forming glaciotectonic moraine complexes. Profile $\mathrm{K} 1$ is situated in laminated lacustrine sediments which are exposed within the $M_{1 c}$ moraine. These lake sediments show micro-fault structures and are likely to have been transported en bloc, possibly as a frozen slab. OSL (post-IR) dating of these sediments yielded ages of $57.8 \pm 9.1 \mathrm{ka}$ (silt) and $85.5 \pm 10.4 \mathrm{ka}$ (clay), consistent with our morphostratigraphic findings which indicate that formation of the $M_{1 c}$ moraine at Khurgan nuur occurred during the early part of the last glaciation (MIS4).

Khoton nuur lies a few kilometres upstream of Khurgan nuur and is dammed by a cross-valley terminal moraine which itself is connected to a glaciofluvial outwash fan that extends into the glaciolacustrine sediments of Khurgan nuur. At the northern side of Khoton nuur, very extensive sets of stacked lateral moraines and kame terraces are found (see Fig. 5). Section K2 is situated down-valley of Khoton nuur, where the river cuts a $13 \mathrm{~m}$ deep channel across the $M_{1 \text { a }}$ 


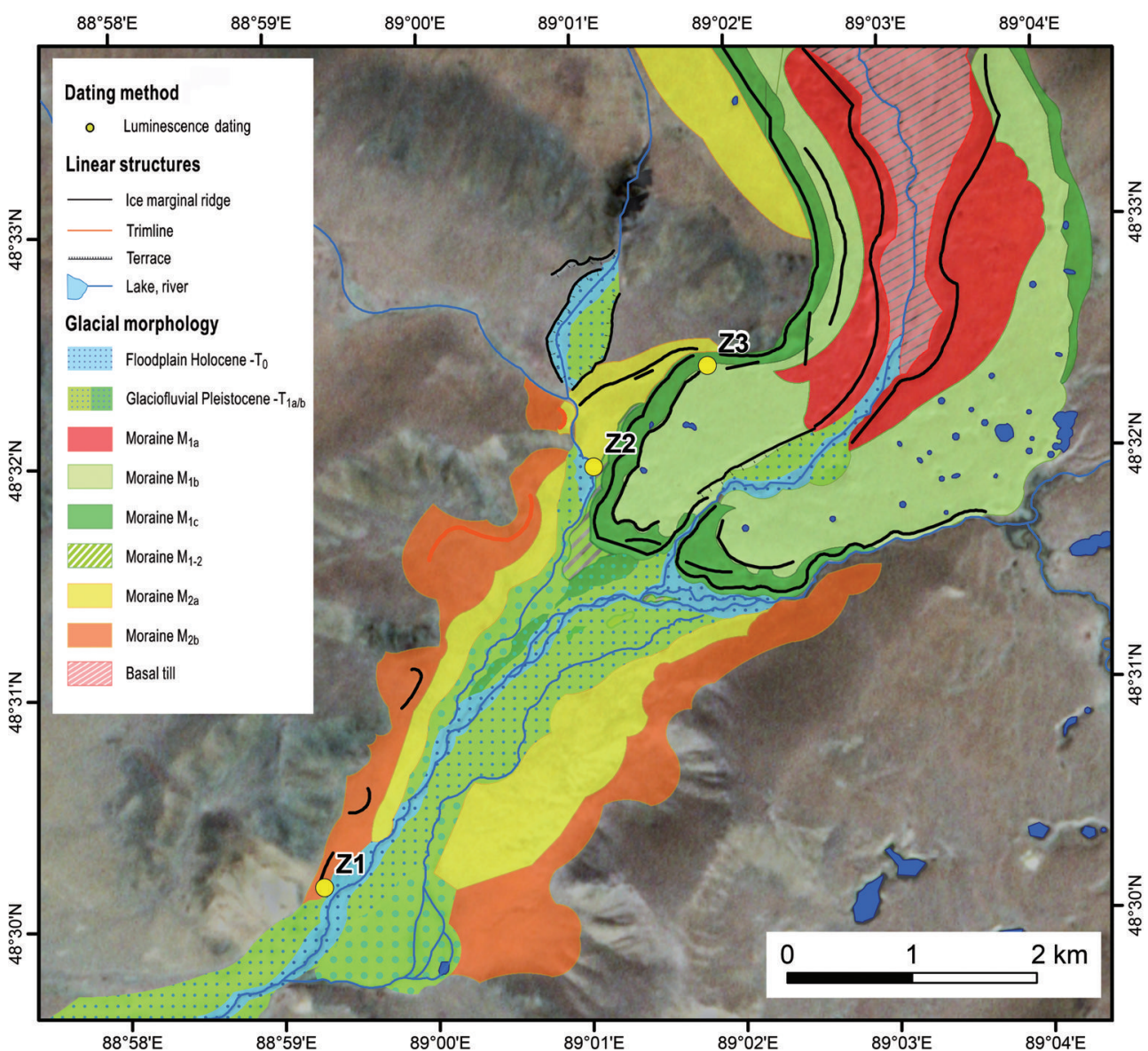

Fig. 3. Geomorphic map of late Quaternary glaciation and sampling of the Tsengel Khairkhan. Background image: SRTM DTM and Landsat 8 image from 9 June 2013.

moraine. Located $1.2 \mathrm{~m}$ below the surface, a layer of silt and sand was dated (OSL) to $>13.6 \pm 1.6 \mathrm{ka}$, supporting our interpretation that the $\mathrm{M}_{1 \mathrm{a}}$ moraine formed during the Lateglacial phase.

The calculation of the LGM $\triangle E L A$ for this area is complicated, because large valley and plateau glaciers, originating from different glaciation centers, coalesced within the Khoton-Khurgan trough. At present, ELAs decrease eastward from about 3400 to 3220 ma.s.I. (at Khovd gol, $3790 \mathrm{~m}$ a.s.l.), while the elevation of the intermontane basin itself limits the lowest position of the maximal terminal moraine to $2050 \mathrm{~m}$ a.s.l. This would indicate a general late Pleistocene (LLGM) ELA at $\sim 2900$ ma.s.l., resulting in a $\triangle \mathrm{ELA}$ of $400 \mathrm{~m}$ for Khurgannuur glacier.

\subsection{Results from other study sites in the Mongolian Altai}

Mapping by Lehmkuhl (1998) in the Turgen-Kharkhiraa mountains (Fig. 1a, No. 4) found almost no moraines preserved between the above-described LIA limits and the late Pleistocene LLGM ice margin. Based on luminescence dating of aeolian cover beds overlying the local moraines, alluvial fans and lake terraces, Grunert and others (2000) suggested two major ice advances in the area and correlated them to expanded glaciation during MIS2 and 4. Pötsch and others (2015) presented new CRN dating results from the Kharkhiraa gol valley supporting this view. Their results indicate major ice advances during early MIS4 (74-71 ka) and MIS2 (25-20 and 18-17 ka). During the late Pleistocene,

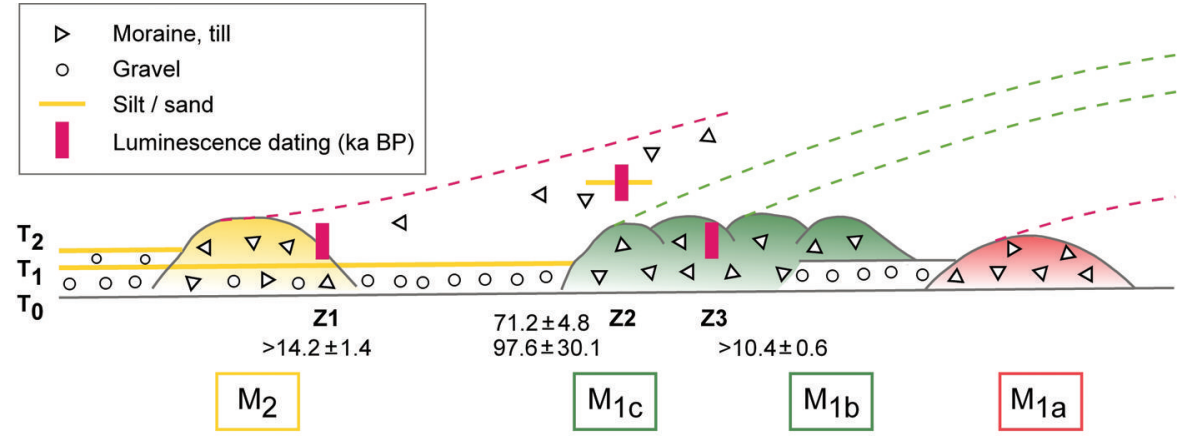

Fig. 4. Schematic cross sections showing the connection between ice-marginal moraines, terraces and aeolian cover beds at Tsengel Khairkhan. 


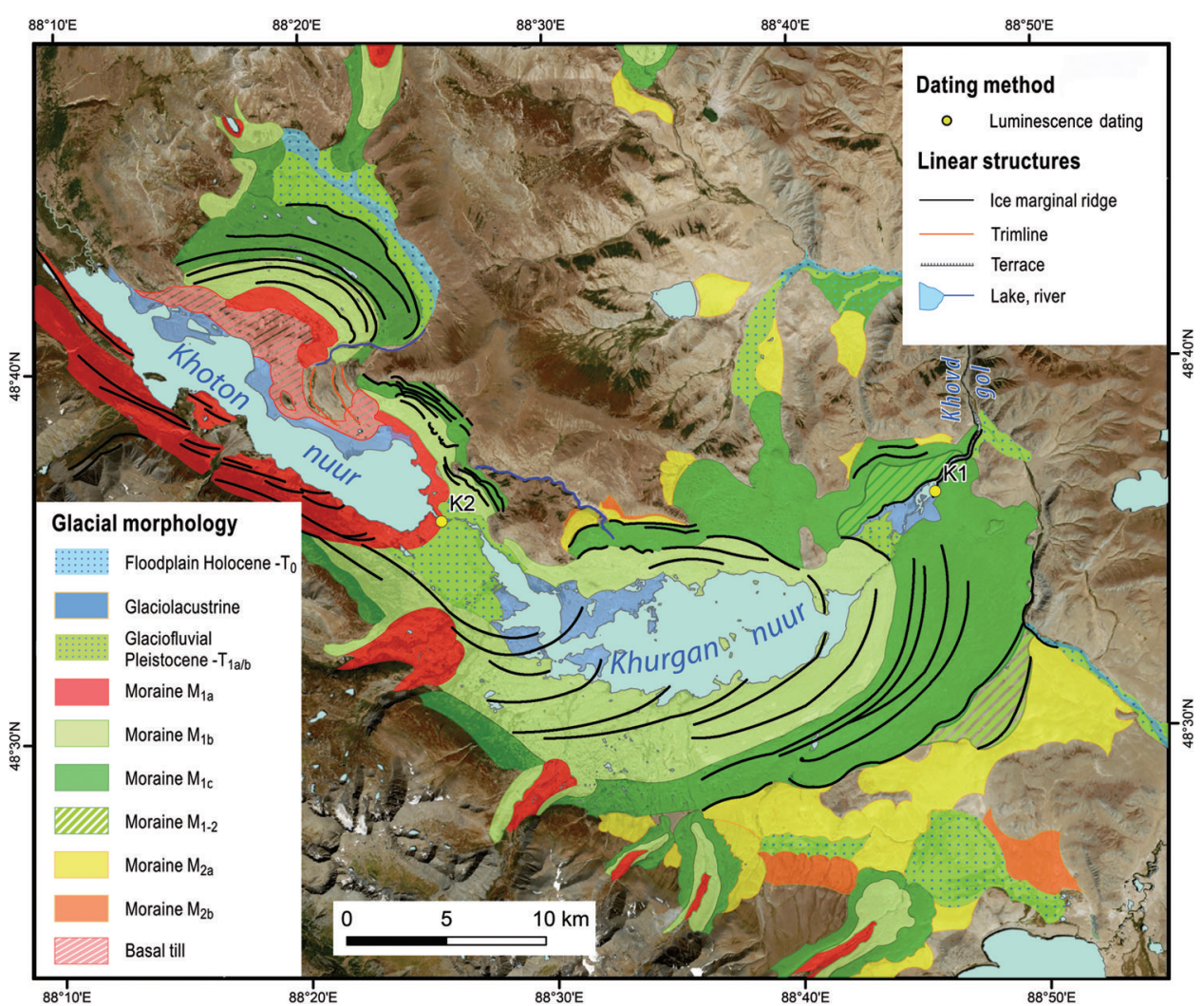

Fig. 5. Geomorphic map of late Quaternary glacial landforms and sampling sites in the surrounding of the Khurgannuur area. Background image: SRTM DTM and Landsat 8 image from 31 August 2014.

local glaciers extended down to 1950 ma.s.l. in the north and to $2250 \mathrm{~m}$ a.s.I. in the south. The modern ELA in the Turgen-Kharkhiraa is at $\sim 3550 \mathrm{~m}$ and we calculated a spatially averaged LGM $\Delta$ ELA of $\sim 520 \mathrm{~m}(430-600 \mathrm{~m})$.

The Tsambagarav is an isolated mountain massif (central Mongolian Altai; Fig. 1a, No. 5) bordered by active faults. In the northwest, river incision at the mountain front provides a $10 \mathrm{~m}$ section exposing a sequence of fanglomerates. At the base a $\sim 1 \mathrm{~m}$ layer of fluvial sand separates the fanglomerates from underlying till. This layer was IRSL-dated to $57.0 \pm 17.0 \mathrm{ka}$ (Klinge, 2001) and places the till into the beginning of the last glacial cycle $\left(\mathrm{M}_{1 \mathrm{c}} ; \mathrm{MIS} 4\right)$ or the penultimate glaciation $\left(\mathrm{M}_{2}\right)$. The Pleistocene $\Delta \mathrm{ELA}$ was $575 \mathrm{~m}$.

At Munkh Khairkhan (southern Mongolian Altai; Fig. 1a, No. 6) the glacial morphology resembles the morphostratigraphic patterns described from previous sites (Klinge, 2001). At the northern slope an intermontane basin without outflow was blocked by $M_{1}$ and $M_{2}$ lateral moraines. The recent lake has cut a section of $4.4 \mathrm{~m}$ into fine clastic lake deposits alternating with peat layers. The radiocarbon analysis of organic material yielded calibrated ${ }^{14} \mathrm{C}$ ages between 28.9 and $42.2 \mathrm{ka}$ BP (Klinge, 2001), in which the higher lake levels indicate moist, warm conditions during MIS3. During the LLGM the $\triangle \mathrm{ELA}$ was $\sim 500 \mathrm{~m}$.

In summary these findings contribute more OSL dates to support the large glacier extension during MIS3 at Otgontenger, and previously undocumented LLGM during MIS2 and 4 in western Mongolia.

\section{DISCUSSION}

\subsection{Extent of modern, Holocene and late Quaternary glaciations}

For the wider study area and under present conditions, glaciation is more extensive in the Russian Altai, with a

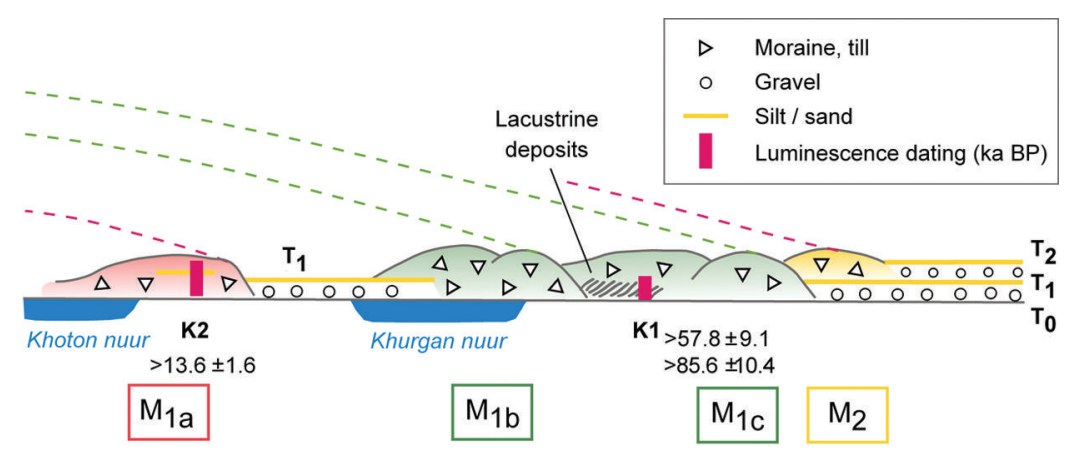

Fig. 6. Schematic cross sections showing the connection between ice-marginal moraines, terraces and aeolian cover beds in the area surrounding the Khurgan nuur. 


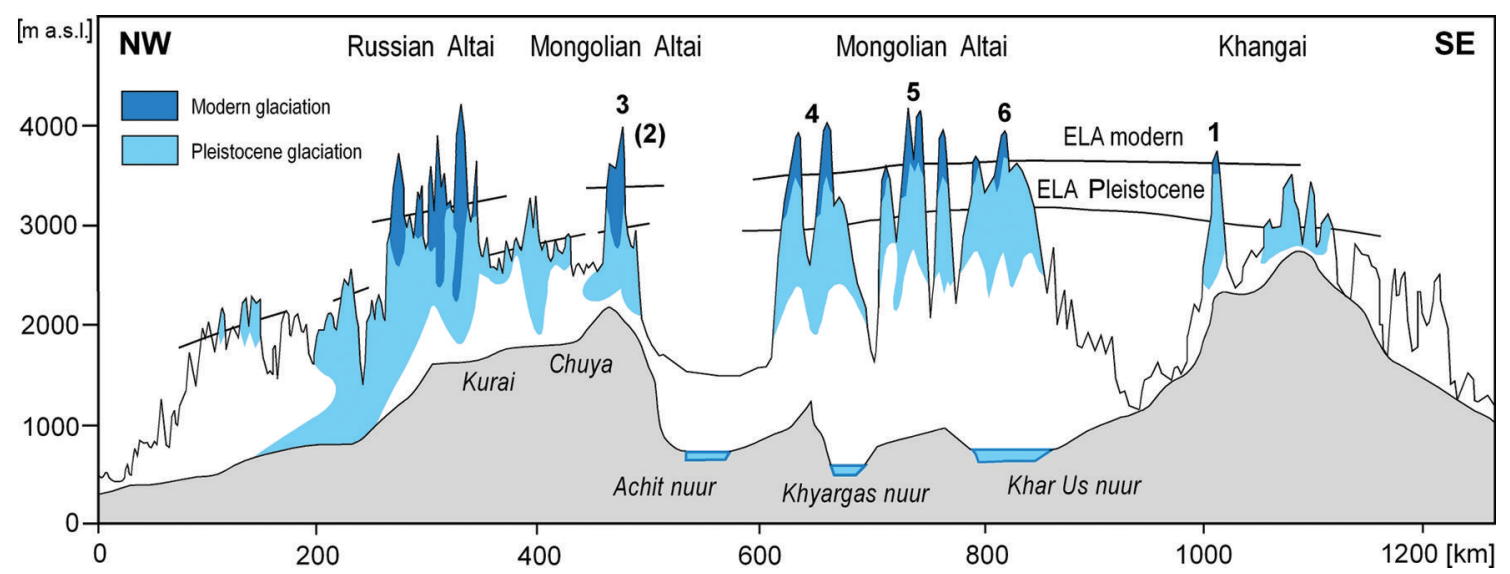

Fig. 7. West-east cross section of the Altai showing modern and Pleistocene glaciations and ELAs. The profile is along the transect shown in Figure 1a (green line). Key sites shown in Figure 1.

modern ELA between 2660 and $3000 \mathrm{~m}$. In the central Altai, only two larger valley glaciers are present on the eastern side of Tavan Bogd, with the glaciated area becoming limited eastwards towards the Mongolian Altai due to reduced precipitation in the lee of the Russian Altai. In the Mongolian Altai separated and smaller glaciation centers, each comprising plateau, cirque and smaller valley glaciers, indicate that the modern ELA rises eastwards from $3300 \mathrm{~m}$ to $>3800 \mathrm{~m}$.

Extensive Holocene moraines, including the morphologically prominent LIA ice margin, are common features throughout the Altai region. For the study areas discussed in this paper, the $\triangle$ ELA during the LIA was $80-30 \mathrm{~m}$. However, the total glaciated area was nearly twice as large as current values. There is also evidence for the trend of smaller $\Delta E L A s$ and ice extension during the LIA in the more arid regions of the Altai.

In many parts of the formerly glaciated areas of the Mongolian Altai the Late-glacial $M_{1 a}$ terminal moraines are rare and often missing, while there are several valleys preserving extensive retreat stages in the Khangai mountains, most prominently in valleys on the eastern slopes of Otgontenger. In between these two regions the maximum ice advance reached terminal ice positions within the limits of the mountain massifs, but in some cases glaciers reached the foreland areas (e.g. Tsengel Khairkhan, Ikh Turgen). Pronounced valley glaciers $(>50 \mathrm{~km})$ occurred only in the Tavan Bogd area (Khurgan nuur, Tsagaan gol). The maximum ELA lowering during the LGM is recorded for the western Altai and Khangai regions (up to $1000 \mathrm{~m}$ ), while the $\Delta \mathrm{ELA}$ in the Mongolian Altai was 300-600 m (Fig. 7).

\subsection{Timing of late Quaternary glaciations and paleoclimatic implications}

Widespread remnants of the $\mathrm{M}_{2}$ moraines indicate a general trend of slightly greater ice extent during the penultimate glaciation (compared to the last glacial cycle). However, more detailed mapping and sampling is still required to accurately delineate the extent of ice and numerical chronology for this period. In contrast, ice extent and morphological characteristics of glacial features generated during the last glacial cycle are well documented. Recent advances in the numerical dating of glacial moraines in Mongolia demonstrate that the timing of formation of the $M_{1 c}$ moraine, which commonly represents the LLGM, falls into MIS4 for western Mongolia and into MIS3 for central Mongolia. The underlying pattern shows that in the Mongolian Altai large ice advances occurred during MIS4 (74-71 ka) and during MIS2 (25-20 and 18-17 ka), while there appears to have been no significant ice expansion during MIS3.

For the Russian Altai, Lehmkuhl and others (2007) published four luminescence age determinations from sand and silt layers between till units ranging from 28 to $19 \mathrm{ka}$ suggesting deposition during MIS2. In addition, Reuther and others (2006) showed that outburst floods from formerly glacier-dammed lakes occurred down the $\mathrm{Ob}$ river which date to $15.8 \pm 1.8 \mathrm{ka}\left({ }^{10} \mathrm{Be}\right)$, suggesting that MIS2 glaciers had retreated from their maximum extents at this time.

In the Kanas river valley (Chinese Altai; Fig. 1a, No. 7) late Quaternary glacier fluctuations generated four different moraine systems and associated glaciofluvial deposits. The largest glacial advances occurred during MIS4 ( 73 ka), mid-MIS3 (52-38 ka) and MIS2 (28-16 ka) (Zhao and others, 2013). According to their results, the modern ELA lies between 3020 and $3360 \mathrm{~m}$ a.s.I. and the LIA moraines are located $\sim 200 \mathrm{~m}$ below the modern glacier margins, suggesting a $\triangle E L A$ of $\sim 100 \mathrm{~m}$. During the LLGM (MIS4) the $\triangle E L A$ was about $600-700 \mathrm{~m}$.

In northern Mongolia, in the Darhad basin, the major advances of the LGM occurred during MIS2 (17-19 ka) and MIS3 (35-53 ka) (Gillespie and others, 2008). For the Otgontenger area in the western Khangai, CRN data presented by Rother and others (2014) supported by new OSL data (this study) suggest major ice expansion during MIS3 (40-35 ka) and during MIS2 (at 23 and 17-16 ka).

In the larger context of understanding the signature of late Quaternary glaciations across central Asia, an increasing number of numerical dates from recent studies reveals the irregular pattern of the extent and timing of the LLGM (Rother and others, 2014). In high- to mid-latitude areas, maximum late Pleistocene glacier advances are commonly recorded during the global temperature minima associated with MIS2 and MIS4, while at lower latitudes, particularly where glaciation was limited by sparse precipitation, LLGM limits were often reached during the warmer but wetter conditions of the MIS3 interstadial. The hydrological limitation in these semi-arid to arid regions of Mongolia can also be observed in the development of permafrost features. Although mountainous areas in western Mongolia generally 
feature a mean annual air temperature below $0^{\circ} \mathrm{C}$, which supports periglacial forms and processes, they occur exclusively at sites where additional groundwater is available under present conditions.

Local climatic conditions and their past variability have exerted a major influence on the dynamics of glaciation in the Altai region, particularly where the moisture supply is the critical limiting parameter. To fully understand the spatial and chronological pattern of glaciation in Mongolia we consider it necessary to include past lake level fluctuations, which can serve as a proxy for reconstructing humidity variations and provide, at times of high lake stands, an important source of additional humidity. For example, elevated lake levels have been documented for the Late-glacial phase and MIS3 periods across a wider region of central Asia and particularly in Mongolia (Grunert and others, 2000; Komatsu and others, 2001). Similarly, evidence for high lake levels during these phases was found at Tsetseg nuur $\left(46^{\circ} 36^{\prime} \mathrm{N}, 93^{\circ} 11^{\prime} \mathrm{E}\right)$, in the eastern Mongolian Altai, based on IRSL-dating of sandy beach walls giving an age of $31.1 \pm 3.8 \mathrm{ka}$, and a radiocarbon age on a mollusk yielding an age of $13.2 \pm 0.3 \mathrm{cal}$. ka BP (Klinge and Lehmkuhl, 2013). At Khar Us nuur $\left(47^{\circ} 51^{\prime} \mathrm{N}, 92^{\circ} 01^{\prime} \mathrm{E}\right)$, the authors found aeolian sediments beneath a beach wall. The beach wall represents a paleo-lake level $\sim 20 \mathrm{~m}$ higher than at present. An IRSL-dating of the aeolian sediment shows $17.1 \pm 3.6 \mathrm{ka}$ and arranges this higher lake level into the Late-glacial phase.

The rain-shadow effect in the Mongolian Altai explains the increased aridity of this region and the limited extent of glaciation, while the Russian and Chinese Altai receive more precipitation, which is mainly delivered by the zonal westerlies. Further to the east, in the Khangai, the air masses may have absorbed additional humidity supplied from large paleo-lakes. This combination may serve as an explanation for the occurrence of Late-glacial phase and MIS3 stages in central Mongolia.

\section{CONCLUSION}

Modern and LIA glaciers are restricted to mountains reaching above $3400 \mathrm{~m}$. Coincident with the rising aridity the ELA increases by $600 \mathrm{~m}$ from the western part of the Mongolian Altai to the east. Compared to its modern extent, glaciation during the LIA was twice the size, with a $\triangle E L A$ of 30-80 m.

Clear morphostratigraphy, geomorphology, and development of distinct aeolian cover sheets provide evidence for different Pleistocene glacier stages.

ELA reconstructions provide evidence for different paleoenvironmental conditions. There are regional differences due to paleoclimatic gradients showing more aridity (indicated by low $\triangle E L A s$ ), particularly in the lee of the (western) Altai. In addition, no recessional moraines of Lateglacial phases are preserved, which indicates a lack of humidity during the rapid warming after the LGM.

New dating results (OSL) provide an improved framework for late Pleistocene glaciations in the Mongolian Altai and Khangai. The timing of maximum glacial advances in the Russian Altai, the Khangai and the Darhad basin appears to be approximately synchronous, but differs from the pattern observed in the Mongolian Altai and the Chinese Altai. This supports the view that paleoclimatic conditions in central Asia varied substantially.
It appears that glacial advances were common in Mongolia during MIS4, MIS3 and MIS2. More numerical results are required to understand glacial development in Mongolia during the last glacial cycle.

\section{ACKNOWLEDGEMENTS}

We thank the Deutsche Forschungsgemeinschaft (HI 1398/ 3-1 and LE 730/31-1) for financial support. Fieldwork was supported by the Institute of Geography of the Mongolian Academy of Sciences (D. Dorjgotov, A. Chimegsaikhan). A. Ehrig and D. Falk helped to produce the maps. We thank D. Falk, A. Hilgers, S. Pötsch, G. Stauch, M. Walther and A. Zander for support during the fieldwork and scientific discussions. In addition, we thank Graham Cogley and two anonymous reviewers who helped greatly to improve the paper.

\section{REFERENCES}

Balco G, Stone J, Lifton N and Dunai T (2008) A simple, internally consistent, and easily accessible means of calculating surface exposure ages and erosion rates from Be-10 and $\mathrm{Al}-26$ measurements. Quat. Res., 69, 242-249

Benn DI and Lehmkuhl F (2000) Mass balance and equilibrium-line altitudes of glaciers in high mountain environments. Quat. Int., 65/66, 15-29

Blomdin R and 11 others (2014) Glacial geomorphology of the Altai and Western Sayan Mountains, Central Asia. J. Maps, 10 (doi: 10.1080/17445647.2014.992177)

Bøtter-Jensen L, McKeever SWS and Wintle AG (2003) Optically stimulated luminescence dosimetry. Elsevier, Amsterdam

Dunai T (2001) Influence of secular variation of the geomagnetic field on production rates of in situ produced cosmogenic nuclides. Earth Planet. Sci. Lett., 193, 197-212

Fuchs $M$ and Owen LA (2008) Luminescence dating of glacial and associated sediments: review, recommendations and future directions. Boreas 37, 636-659

Galbraith RF and Green PF (1990) Estimating the component ages in a finite mixture. Nucl. Tracks Radiat. Meas., 17, 196-206

Galbraith RF, Roberts RG, Laslett GM, Yoshida and Olley JM (1999) Optical dating of single and multiple grains of quartz from Jinmium Rock Shelter, Northern Australia: Part I, Experimental design and statistical models. Archaeometry, 41, 339-364

Gillespie AR, Burke RM, Komatsu G and Bayasgalan A (2008) Late Pleistocene glaciers in Darhad Basin, northern Mongolia. Quat. Res., 69, 169-187

Grunert J, Lehmkuhl F and Walther M (2000) Palaeoclimatic evolution of the Uvs Nuur Basin and adjacent areas (Western Mongolia). Quat. Int., 65/66, 171-192

Heyman J (2014) Paleoglaciation of the Tibetan Plateau and surrounding mountains based on exposure ages and ELA depression estimates. Quat. Sci. Rev., 91, 30-41

Hülle D and 7 others (2010) OSL dating of sediments from the Gobi Desert, Southern Mongolia. Quat. Geochronol., 5, 107-113

Huntley DJ and Baril MR (1997) The K content of the K-feldspars being measured in optical dating or in thermoluminescence dating. Ancient TL 15, 11-13

Kamp U, Krumwiede BS, Mc Manigal KG, Pan CG, Walther M and Dashtseren A (2013) The glaciers of Mongolia. INSTAAR Occas. Pap. 61

Klinge M (2001) Glazialgeomorphologische Untersuchungen im Mongolischen Altai als Beitrag zur jungquartären Landschaftsund Klimageschichte der Westmongolei. Aach. Geogr. Arb., 35

Klinge M and Lehmkuhl F (2013) Geomorphologic map of Tsetseg Nuur Basin, Mongolian Altai - lake development, fluvial sedimentation and aeolian transport in a semi-arid environment. J. Maps, 9, 361-366 
Komatsu G, Brantingham PJ, Olsen J and Baker V (2001) Paleoshoreline geomorphology of Böön Tsagaan Nuur, Tsagaan Nuur and Orog Nuur: the Valley of Lakes, Mongolia. Geomorphology, 39, 83-98

Krumwiede BS, Kamp U, Leonard GJ, Kargel JS, Dashtseren A and Walther M (2014) Recent glacier changes in the Mongolian Altai Mountains: case studies from Munkh Khairkhan and Tavan Bogd. In Kargel JS, Leonard GJ, Bishop MP, Kääb A and Raup B eds Global Land Ice Measurements from Space. Praxis-Springer, Berlin, 229-239

Lehmkuhl F (1998) Quaternary glaciations in central and western Mongolia. Quat. Proc., 6, 153-167

Lehmkuhl F (2012) Holocene glaciers in the Mongolian Altai: an example from the Turgen-Kharkhiraa-Mountains. J. Asian Earth Sci., 52, 12-20

Lehmkuhl F, Klinge M and Stauch G (2004) The extent of late Pleistocene glaciations in the Altai and Khangai Mountains. In Ehlers J and Gibbard PL eds Quaternary glaciations - extent and chronology, Part III: South America, Asia, Africa, Australia, Antarctica. Elsevier, Amsterdam, 243-254

Lehmkuhl F, Frechen M and Zander A (2007) Luminescence chronology of fluvial and aeolian deposits in the Russian Altai (Southern Siberia). Quat. Geochronol., 2, 195-201

Lehmkuhl F, Klinge M and Stauch G (2011) The extent and timing of Late Pleistocene Glaciations in the Altai and neighbouring mountain systems. In Ehlers J, Gibbard PL, Hughes PL and Hughes PD eds. Developments in Quaternary Science: extent and chronology - a closer look, 15, 967-979

Lehmkuhl F, Hülle D and Knippertz M (2012) Holocene geomorphic processes and landscape evolution in the lower reaches of the Orkhon Valley (northern Mongolia). Catena 98, $17-28$

Osipov EU, Ashmetev AP, Osipova ON and Klevtsov EB (2013) Novaya inventarizatsiya lednikov v yugo-vostochnoj chasti Vostochnogo Sayana. Led i Sneg, 123, 45-54 [in Russian]

Pfeffer WT and 75 others (2014) The Randolph Glacier Inventory: a globally complete inventory of glaciers. J. Glaciol., 60(221), 537-551 (doi: 10.3189/2014JoG13J176)

Pötsch S, Rother H, Lorenz S, Walther M and Lehmkuhl F (2015) Timing of late Pleistocene glaciation in Mongolia: surface exposure dating reveals a differentiated pattern of ice advances. Geophys. Res. Abstr., 17

Prescott JR and Hutton JT (1995) Environmental dose rates and radioactive disequilibrium from some Australian luminescence dating sites. Quat. Sci. Rev. 14, 439-448

Reuther AU, Herget J, Ivy-Ochs S, Borodavko P, Kubik PW and Heine K (2006) Constraining the timing of the most recent cataclysmic flood event from ice-dammed lakes in the Russian Altai Mountains, Siberia, using cosmogenic in situ ${ }^{10} \mathrm{Be}$. Geology 34(11), 913-916

Rother H, Lehmkuhl F, Fink D and Nottebaum V (2014) Timing of late Pleistocene glaciations in the Khangai Mountains of Mongolia: evidence for a MIS 3 glacial maximum. Quat. Res., 82, 297-308

Thiel C and 6 others (2011) Luminescence dating of the Stratzing loess profile (Austria) - testing the potential of an elevated temperature post-IR IRSL protocol. Quat. Int. 234, 23-31

Zhao J, Yin X, Harbor JM, Lai Z, Liu S and Li Z (2013) Quaternary glacial chronology of the Kanas River valley, Altai Mountains, China. Quat. Int. 311, 44-53 